\title{
PHOTODIODE BASED PROTOTYPE DEVICE FOR SKIN AUTOFLUORESCENCE PHOTOBLEACHING DIAGNOSTICS IN DERMATOLOGY
}

\author{
I. Ferulova $^{\text {a }}$, A. Rieba ${ }^{\text {a }}$,. Lesins ${ }^{\text {a }}$, A. Berzina ${ }^{\text {b }}$, A. Lihachev ${ }^{\text {a }}$, and J. Spigulis ${ }^{\text {a }}$ \\ ${ }^{a}$ Institute of Atomic Physics and Spectroscopy, University of Latvia, Raina 19, LV-1586 Riga, Latvia \\ E-mail: inesa.ferulova@gmail.com \\ ${ }^{\mathrm{b}}$ Laserplastic Clinic, Baznīcas 31, LV-1010 Riga, Latvia
}

Received 27 August 2011; revised 1 February 2012; accepted 1 March 2012

\begin{abstract}
A new portable non-invasive prototype device for skin autofluorescence photobleaching measurements under a $532 \mathrm{~nm}$ laser excitation has been developed and clinically tested. The details of the equipment are described along with some measurement results illustrating the potentiality of the technology. Overall, 51 malformations of human skin were investigated by the device.
\end{abstract}

Keywords: skin, autofluorescence, photobleaching, prototype device, photodiode

PACS:87.64.kv

\section{Introduction}

Laser radiation is widely exploited in dermatology for diagnostics and treatment of skin diseases, using a wide range of laser wavelengths and radiation powers [1]. The potential of autofluorescence photobleaching (AFPB) for skin clinical diagnostics is of particular interest.

The AFPB is a decrease of fluorescent intensity during optical excitation [2, 3]. The AFPB of human skin has been studied at various pulsed and $\mathrm{cw}$ laser excitation wavelengths: ultraviolet $(337 \mathrm{~nm})$, violet $(405 \mathrm{~nm})$, blue $(442 \mathrm{~nm})$, green $(532 \mathrm{~nm})$, and red $(632 \mathrm{~nm})$ [4]. The temporal behaviour of the skin AFPB can be well described by the double exponential equation (1), where the parameters $\tau_{1}$ and $\tau_{2}$ characterise the fast and slow phases of AFPB, and $A$ is a background level of intensity $I[5,6]$ :

$$
I(t)=A+A_{1} \exp \left(-t / \tau_{1}\right)+A_{2} \exp \left(-t / \tau_{2}\right) .
$$

The results of clinical studies showed that parameter $\tau_{1}$ significantly differs between healthy skin and skin with pathologies of the same person. Our previous research proved that the increased content of melanin in the skin slows down the AFPB process under the green laser $532 \mathrm{~nm}$ excitation [4, 5, 7]. The AFPB might have a promising potential for skin clinical diagnostics.

In this paper a newly developed prototype device is described. It comprises a built-in photodiode for the skin autofluorescence (AF) detection instead of the previously used spectrometry set-up [4, 7]; such design simplifies detection and would reduce the costs of production.

\section{Method and equipment}

A continuous low power laser irradiation is used for the skin AF excitation at a visible wavelength of $532 \mathrm{~nm}$. A set-up scheme of the prototype device is presented in Fig. 1. The skin AF is excited by a low power DPSS $532 \mathrm{~nm}$ laser (Huanic DD532-10-3) with output power density being $32 \mathrm{~mW} / \mathrm{cm}^{2}$. The intensity of AF is detected by a silicon photodiode (OPT101) with an amplifier registered by a 16-channel voltage data logger (PicoLog 1216) and saved at a laptop computer. A combination of 2 long pass filters 


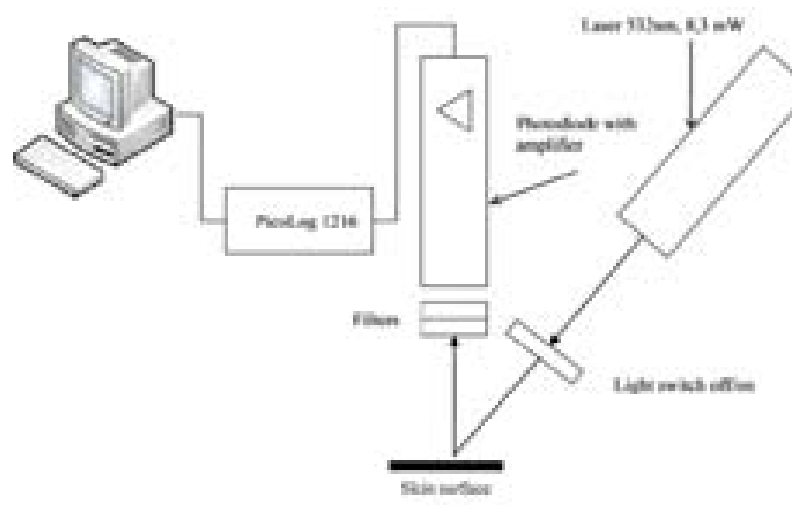

Fig. 1. A set-up scheme of the prototype device.

in front of the photodiode, Semrock BLP01-532R and Eksma OG570/KG3, is ensuring a transmission window between 550 and $650 \mathrm{~nm}$ in ord duced skin AF of this wavelength range. The distance between the skin surface and the filters is $3 \mathrm{~mm}$. The photodiode is installed orthogonally to the skin surface, and the exciting laser beam forms a $45^{\circ}$ slope angle to the skin surface. The AFPB data of skin pathology is recorded for about $30 \mathrm{~s}$ (signal integration time is $1 \mathrm{~ms}$ ), and then the AF of healthy skin near pathology is measured for comparison. The prototype device provides the ambient light isolation during the measurements, reducing the background noise.

\section{Results}

Overall, 51 patients in the Riga Laserplastic Clinic were investigated by means of the portable noninvasive prototype device (Fig. 2). The safety and well-being of patients involved in a clinical trial were provided according to permission of the local ethics committee. The initial AF intensity of healthy skin near pathology was always higher in tensity of a healthy skin area was equally high in all cases, but the AF intensity for various pathologies was notably lower according to the degree of pigmentation. The pathologies were classified into two groups, of high and of low pigmentation. The ratio between the initial $A F$ intensity of healthy kin and the AF intensity of high pigme pathologies was distributed within the interva of 2.3-4.8, and of low pigmentation pathologies within the interval of 1.2-1.7.

The recorded AFPB data were analysed and the parameters of Eq. (1) were calculated by fitting. For illustration, the AFPB time series taken from are presented in Fig. 3, along with photobleaching parameters. The AFPB effect was not observed on high pigmentation pathologies during $30 \mathrm{~s}$ of measurement. In case of pigmentation pathology the value of parameter $\tau_{1}$ was always relatively higher than its value for healthy skin of the same person.

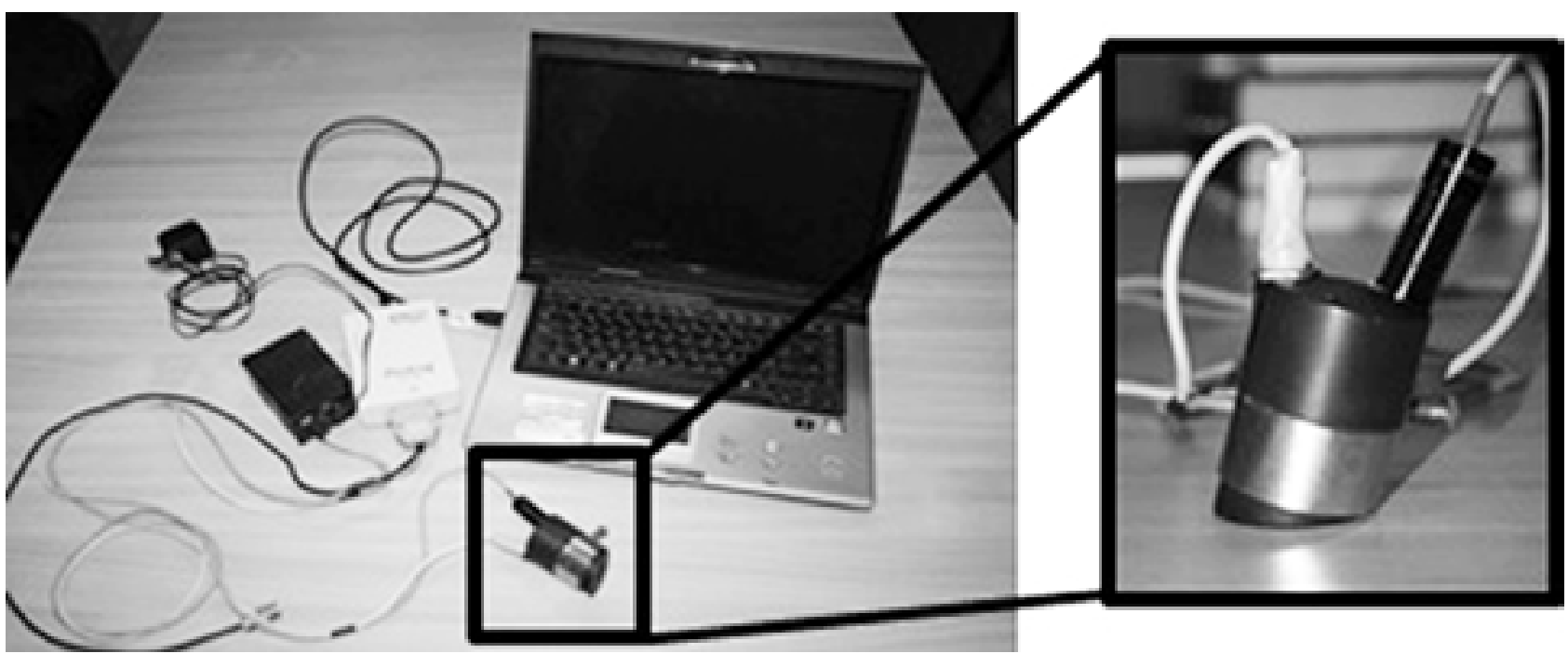

Fig. 2. View of the photodiode based prototype device set-up (left) and the zoomed prototype device (right).

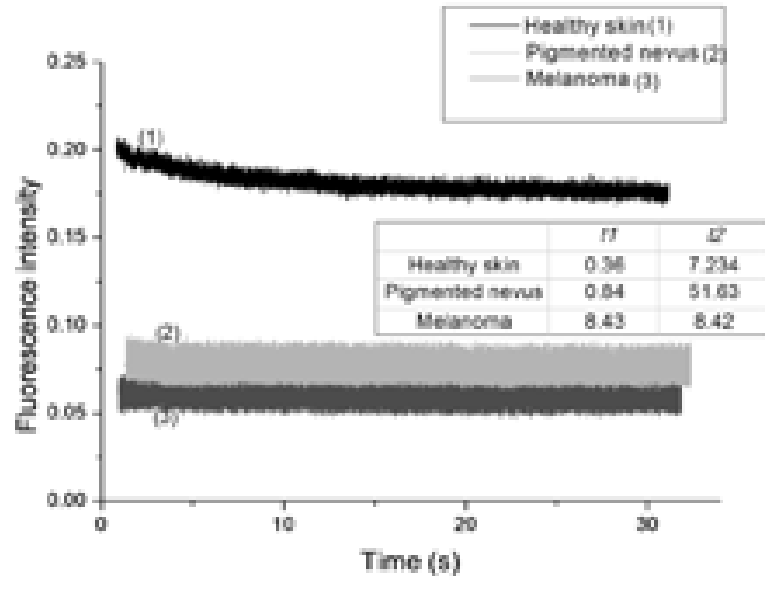

Fig. 3. AFPB time dependence taken from healthy skin and pigment nevus, with the corresponding photobleaching parameters $\left(t 1, t 2\right.$ correspond to $\tau_{1}$ and $\left.\tau_{2}\right)$

The results obtained with the prototype device showed AF intensity bleaching by $8 \%$, while previous studies with the spectrometry set-up proved AFPB up to $30 \%$ (in 30 seconds). The AFPB dependence on the equipment integration time was compared (Fig. 4) for the purpose of device testing. Significantly reducing the integration time of the significanty reding the in pectrometer, the changes of AFPB dynamics were similar to the results of photodiode based device measurements.

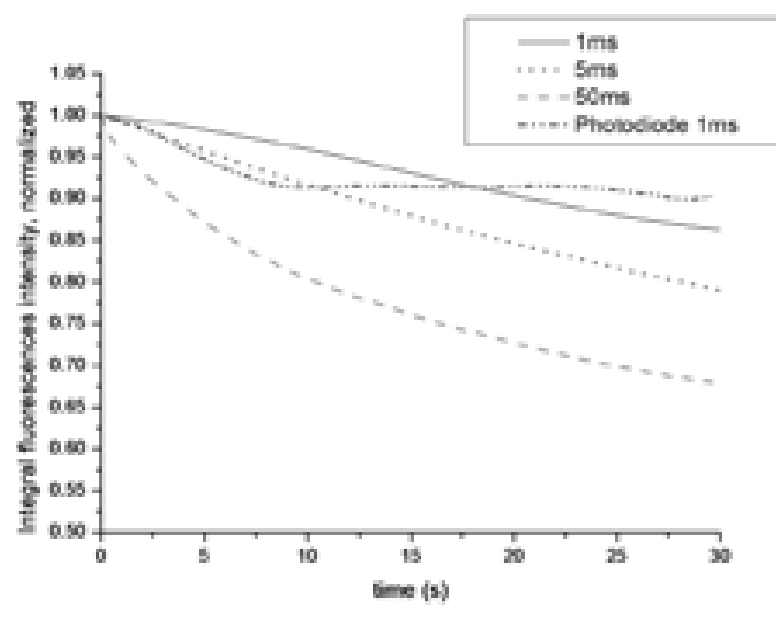

Fig. 4. AFPB at various integration times of the spectrometer and photodiode, taken from healthy skin.

\section{Conclusions}

A prototype device for skin AF recording was produced and clinically tested. Overall, 51 persons with pigmented skin pathologies were investigated by a new prototype device. AF intensity values and temporal changes of fluorescent intensity can be recorded by the prototype device, with subsequent calculation of relative changes and photobleaching parameters $(\tau, \tau, A)$. Analysis of the clinical the data to-noise ratio and to fully avoid registration of the scattered laser radiation. Further investigation will focus on the device integration time adjustment based on changes in representation of AFPB dynamics.

\section{Acknowledgments}

This work was partially funded by the European Social Fund project No. 2009.0211/1DP/1.1.1.1 2.0/09/APIA/VIAA/077FP7 and the EC FP7 project "Laserlab-Europe" (JRA4 OPTBIO), contract No. 228334.

\section{References}

[1] Laser Surgery and Medicine, eds. A. Carmen and M.D. Puliafito (John Wiley \& Sons Inc., New York, 1996)

[2] Y.P. Sinichkin, N. Kollias, G.I. Zonios, S.R. Utz and V.V. Tuchin, Reflectance and fluorescence spectroscopy of human skin in-vivo, in: Handbook of Optical Biomedical Diagnostics, ed. V.V. Tuchin (SPIE Press, 2002) pp. 725-785.

[3] E.V. Salomatina and A.B. Pravdin, Fluorescence dynamics of human epidermis (ex vivo) and skin (in vivo), Proc. SPIE 506b, 405-410 (2003).

[4] A. Lihachev and J. Spigulis, Skin autofluorescence fading at 405/532 nm laser excitation, IEEE Xplore 10.1109/NO, 63-65 (2007)

[5] A. Lihachev, J. Spigulis, and R. Erts, Imaging of laser-excited tissue autofluorescence bleaching rates, Appl. Opt. 48(10), D163-D168 (2009).

[6] A. Stratonnikov, V. Polikarpov, and V. Loschenov, Photobleaching of endogenous fluorochroms in tissues in vivo during laser irradiation, Proc. SPIE 4241, 13-24(2001).

[7] A. Lihachev, J. Lesinsh, D. Jakovels, and J. Spigulis Low power cw-laser signatures on skin, Quant lectron. 40(12), 1077-1080 (2010). 


\title{
Fotodiodinio ịtaiso prototipas odos autofluorescencinei fotoišbalinimo diagnostikai dermatologijoje
}

\author{
I. Ferulova ${ }^{\text {a }}$, A. Rieba ${ }^{\text {a }}$, J. Lesins ${ }^{\text {a }}$, A. Berzina ${ }^{\text {b }}$, A. Lihachev ${ }^{\text {a }}$, J. Spigulis ${ }^{\text {a }}$ \\ ${ }^{a}$ Latvijos universiteto Atomines fizikos ir spektroskopijos institutas, Ryga, Latvija \\ ${ }^{\mathrm{b}}$ Lazerinés plastikos klinika, Ryga, Latvija
}

\section{Santrauka}

Sukurtas ir kliniškai išbandytas naujas prototipinis nešiojamas neinvazinis įrenginys, skirtas odos autofluorescenciniam fotoišbalinimui matuoti, naudojant
$532 \mathrm{~nm}$ lazerio žadinimą. Pateiktas smulkus įrangos aprašas ir kai kurie matavimo rezultatai, iliustruojantys šio būdo galimybes. Iš viso šiuo prietaisu ištirtas 51 žmogaus odos probleminis darinys. 